\title{
Pengaruh Model Pembelajaran Kooperatif Tipe Make A Match terhadap Motivasi dan Hasil Belajar Matematika
}

\author{
Ayu Anggita Anggraeni ${ }^{*}$, Veryliana P. ${ }^{2}$, Ibnu Fatkhu R. ${ }^{3}$
}

${ }^{123}$ Jurusan Pendidikan Guru Sekolah Dasar, FIP, Universitas PGRI Semarang, Indonesia

\begin{tabular}{l} 
A R T I C L E I N F O \\
\hline Article history: \\
Received 18 February \\
2019 \\
Received in revised form \\
20 March 2019 \\
Accepted 20 April 2019 \\
Available online 20 May \\
2019 \\
\\
\hline Kata Kunci: \\
Pengaruh, Model \\
Pembelajaran Make A \\
Match, Motivasi Belajar, \\
Hasil Belajar \\
Keywords: \\
Influence, Make A Match \\
Learning Model, Learning \\
Motivation, Learning \\
Outcomes
\end{tabular}

\section{A RT I C LEINFO} 2019

Available online 20 May

Pembelajaran Make A

Match, Motivasi Belajar

Keywords:

Learning Model, Learning

Outcomes

\begin{abstract}
A B S T R A K
Penelitian ini bertujuan untuk mengetahui pengaruh model pembelajaran kooperatif tipe make a match pada materi bangun datar kelas V SDN 1 Balun Banjarnegara dilihat pada motivasi dan hasil belajar siswa. Jenis penelitian ini adalah penelitian kuantitatif dalam bentuk Quaisi Experimental Design dengan desain Nonequivalent Control Group Design. Populasi penelitian adalah seluruh siswa kelas V SDN 1 Balun Banjarnegara tahun pelajaran 2018-2019. Sampel yang diambil adalah siswa kelas $\mathrm{V}$ A berjumlah 22 siswa dan siswa kelas $\mathrm{V} B$ berjumlah 21 siswadengan menggunakan teknik Non Probability Sampling. Data dalam penelitian ini diperoleh melalui dokumentasi, observasi, angket, dan tes. Hasil analisis angket motivasi siswa menunjukan bahwa presentase kelompok eksperimen (90,91\%) lebih besar dari kelompok kontrol $(57,14 \%)$, serta berdasarkan hasil hitung uji t diketahui $t_{\text {hitung }}$ lebih besar dari $t_{\text {tabel }}(2,995>2,021)$. Kesimpulannya bahwa model pembelajaran Make $A$ Match berpengaruh terhadap motivasibelajar siswa. Nilai kelompok eksperimen diketahui rata-rata 65,91 lebih besar dari kelompok kontrol 49,05, serta berdasarkan hasil uji t di ketahui $t_{\text {hitung }}$ lebih besar dari $t_{\text {tabel }}(6,502>2,01)$.
\end{abstract}

\section{A B S T R A C T}

This study aims to determine the effect of cooperative learning model type make a match on class $\mathrm{V}$ flat building material SDN 1 Balun Banjarnegara viewed on motivation and student learning outcomes. This type of research is quantitative research in the form of Quaisi Experimental Design with the design of Nonequivalent Control Group Design. The study population was all fifth grade students of SDN 1 Balun Banjarnegara school year 2018-2019. The sample taken was 22 students of class V A and students of class V B numbered 21 students using the Non Probability Sampling technique. The data in this study were obtained through documentation, observation, questionnaires, and tests. The results of student motivation questionnaire analysis showed that the percentage of the experimental group (90.91\%) was greater than the control group $(57.14 \%)$, and based on the results of the $t$ test it was known that $\llbracket \mathrm{t} \rrbracket$ _count was greater than $\mathrm{t}$-table $(2.995>2.021)$. In conclusion, the Make A Match learning model has an effect on student learning motivation. The value of the experimental group is known to average 65.91 greater than the control group 49.05, and based on the results of the $\mathrm{t}$ test known 『t 『_count is greater than $\mathrm{t}$ _table $(6,502>2.01)$.

\footnotetext{
${ }^{1}$ Corresponding author.

E-mail addresses: ayuanggita142@yahoo.com (Ayu Anggita Anggraeni)
} 


\section{Pendahuluan}

Pendidikan merupakan prioritas yang paling utama dan penting dalam meningkatkan sumber daya manusia sebagai mana tercantum dalam pembukaan UUD 1945 tujuan pendidikan nasional adalah “ mencerdaskan kehidupan bangsa". Mencapai tujuan pendidikan memerlukan strategi dengan mengembangkan ilmu pengetahuan dan teknologi untuk menciptakan mutu pendidikan yang berkualitas. Menurut Undang-undang Republik Indonesia Nomor 20 Tahun 2003 tentang Sistem Pendidikan Nasional, Pasal 1 Ayat 1 berbunyi " pendidikan adalah usaha sadar dan terencana untuk mewujudkan suasana belajar dan proses pembelajaran agar peserta didik secara aktif mengembangkan potensi dirinya utuk memiliki kekuatan spiritual keagamaan, pengendalian diri, kepribadian, kecerdasan, ahlak mulia, serta keterampilan yang diperlukan dirinya, masyarakat, bangsa, dan negara. Menurut Aliputri (2018) Pendidikan dan pengajaran adalah suatu proses yang sadar tujuan. Tujuan dapat diartikan sebagai suatu usaha untuk memberikan rumusan hasil yang di harapkan siswa setelah melaksanakan pengalaman belajar. Pengalaman belajar bisa didapatkan dimana saja, salah satunya di sekolah. Dalam pembelajaran di sekolah tentunya memuat banyak mata pelajaran yang diajarkan. Menurut Fadilah (2014)Peningkatan disuatu negara memang peranan penting dalam pengembangan sumber daya manusia yang berkualitas. Untuk upaya membentuk manusia yang berkualitas dimulai dari keluarga,lingkungaan sosial serta lembaga pendidikan pendidik untuk mengembangkan potensi sumber dayamanusia tersebut diperlukan tenaga pendidik atau guru yang memiliki pengetahuan,ketrampilan dan strategi belajar yang mampu mengantarkan peserta didik mencapai ketuntasan dalam proses pembelajar. Salah satu indikator pendidikan berkualitas adalah perolehan hasil belajar siswa yang optimal, baik hasil belajar dalam bentuk kognitif, afektif maupun psikomotor. Proses belajar mengajar meliputi kegiatan yang dilakukan oleh guru mulai dari perencanaan, pelaksanaan kegiatan sampai evaluasi dan program tindak lanjut yang berlangsung dalam situasi edukatif untuk mencapai tujuan tertentu yaitu pengajaran (Suryosubroto, 1997:19). Dari faktor tersebut dapat disimpulkan bahwa semakin tinggi kemampuan siswa dan kualitas pengajaran maka semakin tinggi pula hasil belajar siswa. Menurut Astika (2011) Pendidikan mempunyai peran yang sangat strategis dalam meningkatkan kualitas sumber daya manusia dan upaya mewujudkan cita-cita bangsa Indonesia dalam mewujudkan kesejahteraan umum dan mencerdaskan kehidupan bangsa. Pemerintah merumuskan dalam Undang-Undang Republik Indonesia No 20 tahun 2003 Pasal 1 tentang Sistem Pendidikan Nasional yang menjelaskan bahwa "Pendidikan adalah usaha sadar dan terencana untuk mewujudkan suasana belajar dan proses pembelajaran agar peserta didik secara aktif mengembangkan potensi dirinya untuk memiliki kekuatan spiritual keagamaan, pengendalian diri, kepribadian, kecerdasan, akhlak mulia, serta ketrampilan yang diperlukan dirinya, masyarakat, bangsa, dan negara. Menurut Durukun (2011) Keberhasilan suatu proses pembelajaran salah satunya ditentukan oleh peran guru dalam mengembangkan metode yang digunakan. Peran guru dalam hal ini adalah bagaimana kreatifitas guru dalam mendesain proses belajar mengajar yang efektif, yaitu proses belajar yang mengembangkan metode dengan penekanan pada partisipasi dan keaktifan siswa di kelas. Penggunaan pola pembelajaran berpusat pada siswa tentunya diharapkan untuk mewujudkan kondisi yang konduktif sehingga mendorong siswa untuk termotivasi melakukan kegiatan belajar secara aktif. Kenyataan di lapangan menunjukkan bahwa tercapainya proses belajar mengajar yang efisien, bukan karena hanya dengan metode yang bersifat berpusat pada guru atau komunikasi satu arah, akan tetapi harus juga dengan metode pembelajaran yang bersifat multi arah atau pembelajaran berpusat pada siswa. Apabila hal ini tidak bersinergi, maka akan mempengaruhi kualitas pendidikan menjadi rendah. Dalam kurikulum 2013 kegiatan proses belajar berpusat pada siswa sehingga memerlukan penggunaan pendekatan pengajaran strategi, metode dan tehnik sesuai dengan pendekatan untuk melibatkan partisipasi siswa aktif dalam proses belajar.

Matematika merupakan ilmu dasar yang sangat berperan bagi perkembangan ilmu pengetahuan dan teknologi serta memajukan daya pikir manusia. Matematika tidak menerima generalisasi berdasarkan pengamatan (induktif), akan tetapi matematika harus berdasarkan pembuktian deduktif. Perlu adanya pengetahuan bahwa baik isi maupun metode mencari kebenaran dalam matematika berbeda dengan ilmu pengetahuan alam apalagi dengan ilmu pengetahuan pada umumnya. Metode mencari kebenaran yang dipakai oleh matematika adalah ilmu deduktif, sedangkan oleh ilmu pengetahuan alam adalah metode induktif.

Menurut Tiballa (2017) Pembelajaran merupakan kegiatan yang mempunyai tujuan, yaitu membelajarkan siswa untuk mencapai kompetensi yang diinginkan. Pembelajaran merupakan suatu hal yang sangat kompleks yang dipengaruhi oleh beberapa faktor antara lain guru, siswa, sarana, media, serta lingkungan. Agar pembelajaran berlangsung efektif, guru memiliki peran yang sangat penting. Guru tidak hanya berfungsi sebagai sumber ilmu, tetapi juga harus berperan sebagai motivator dan fasilitator dalam pengembangan minat peserta didik dalam mencari ilmu pengetahuan secara mandiri. Namun, pada 
kenyataannya guru masih kesulitan untuk mengaktifkan siswa dalam belajar sehingga proses pembelajaran belum memenuhi standar proses sesuai dengan yang diharapkan. Menurut Juhji (2017) Pembelajaran adalah kegiatan yang secara sadar dan sengaja dilakukan guru, sehingga tingkah laku siswa yang meliputi aktivitas dan pola pikir siswa berubah ke arah yang lebih baik, proses ini bertujuan untuk membantu siswa dalam memperoleh berbagai pengalaman dan dari pengalaman tersebut kualitas tingkah laku siswa akan meningkat.Dengan demikian, pembelajaran merupakan suatu sistem yang terdiri atas berbagai komponen yang saling berhubungan satu dengan yang lain. Komponen tersebut diantaranya meliputi: 1) tujuan, 2) materi, 3) metode, dan 4) evaluasi. Keempat komponen pembelajaran tersebut harus diperhatikan oleh pendidik dalam memilih dan menentukan model-model pembelajaran apa yang akan digunakan dalam kegiatan pembelajaran. Cerdik dalam penentuan model pembelajaran tentu akan membawa dampak yang baik bagi hasil belajar peserta didik. Slameto menuliskan bahwa terdapat beberapa faktor yang mempengaruhi hasil belajar siswa, di antaranya adalah: 1) metode mengajar, 2) interaksi guru dengan siswa, dan 3) interaksi siswa dengan siswa. Tujuan umum pembelajaran Matematika sesuai yang dirumuskan dalam Permendiknas No. 22 (2006: 417) yaitu: (1) memahami konsep matematika, menjelaskan keterkaitan antar konsep dan mengaplikasikan konsep atau algoritma, secara luwes, akurat, efisien, dan tepat dalam pemecahan masalah; (2) menggunakan penalaran pada pola dan sifat, melakukan manipulasi matematika dalam membuat generalisasi, menyusun bukti, atau menjelaskan gagasan dan pernyataan matematika; (3) memecahkan masalah yang meliputi kemampuan memahami masalah, merancang model matematika, menyelesaikan model dan menafsirkan solusi yang diperoleh; (4) mengomunikasikan gagasan dengan simbol, tabel, diagram, atau media lain untuk memperjelas keadaan atau masalah; serta (5) memiliki sikap menghargai kegunaan matematika dalam kehidupan, yaitu memiliki rasa ingin tahu, perhatian, dan minat dalam mempelajari matematika, serta sikap ulet dan percaya diri dalam pemecahan masalah.

Berdasarkan hasil wawancara pada tanggal 22 Mei 2018 dengan guru kelas V SD Negeri 1 Balun kabupaten Banjarnegara yaitu Ibu Rumyati.,S.Pd bahwa peneliti menyimpulkan masalah yang dihadapi guru sama. Yaitu motivasi dan hasil belajar siswa yang diakibatkan kurangnya semangat siswa dalam kegiatan belajar, hal tersebut yang memicu motivasi dan hasil belajar siswa belum maksimal pada nilai UTS yang masih kurang dari Kriteria Ketuntasan Minimal (KKM). Nilai KKM Matematika yaitu 60.

Permasalahan-permasalahan di atas membutuhkan suatu solusi. Alternative solusi yang akan peneliti lakukan adalah dengan menerapkan pembelajaran kooperatif. Model pembelajaran yang di terapkan yaitu Make A Match. Menurut Aisyah (2015) Salah satu variasi model pembelajaran yang dapat diterapkan pada kompetensi dasar potongan bahan makanan yaitu model pembelajaran kooperatif tipe Make A Match, karena menurut peneliti dengan model pembelajaran ini siswa lebih aktif karena dituntut untuk mencari tahu dengan mengamati (observing) dan mencocokkan pertanyaan dengan jawaban dari kartu yang berisi beberapa topik, saling bekerja sama (networking), mempresentasikan hasil diskusi dengan mengeluarkan pendapat mengenai topik (associating), bertanya (questioning), dan menerima pendapat dari kelompok lain sehingga siswa lebih memahami konsep-konsep yang dianggap sulit karena berdiskusi secara kelompok, mencoba (experimenting) membuat potongan bahan makanan yang telah dipelajari dengan obyek nyata. Selain itu, model pembelajaran tipe Make A Match merupakan variasi model pembelajaran baru sehingga diharapkan menumbuhkan minat belajar siswa serta memotivasi siswa dalam belajar. Menurut Deschuri (2016) dengan menggunakan model pembelajaran kooperatif teknik Make A Match siswa akan lebih bersemangat karena model pembelajaran tersebut terdapat unsur permainannya, selain itu siswa pun dilibatkan langsung dalam pembelajaran. Teknik Make A Match ini mampu menciptakan kondisi kelas yang interaktif, efektif sebagai sarana untuk melatih keberanian siswa, serta mampu menghilangkan kebosanan siswa ketika pembelajaran berlangsung. Menurut Ernawati (2016) Model Pembelajaran Kooperatif menekankan kerja sama antara siswa dalam kelompok. Hal ini dilandasi oleh pemikiran siswa yang lebih mudah mengemukakan dan memahami suatu konsep jika mereka saling mendiskusikan masalah tersebut dengan temannya. Model pembelajaran kooperatif terdiri beberapa tipe, antara lain Jigsaw, Think-Pair-Share, Numbered Heads Together, Group Investigasion, dan Make a Match. Model Pembelajaran Kooperatif dengan tipe Make a Match diawali dengan pembentukan tiga kelompok. Jika kelas terdiri dari 30 orang, maka masing-masing kelompok berjumlah 10 orang. Kelompok pertama yaitu kelompok pemegang kartu pertanyaan-pertanyaan, kelompok ke dua yaitu kelompok pemegang kartu jawaban-jawaban, dan kelompok terakhir yaitu kelompok penilai. Kemudian diatur posisi kelompok tersebut berbentuk huruf $U$, lalu diupayakan kelompok pertama dan kedua berjajar saling berhadapan. Jika masigmasing kelompok sudah berada pada posisi yang telah ditentukan, maka guru membunyikan peluit sebagai tanda agar kelompok pertama dan kedua bergerak mencari pasangan pertanyaan dan jawaban yang cocok. Setelah kartu-kartu dicocokkan, maka terbentuklah pasangan-pasangan pemegang kartu pertanyaan dan jawaban. Menurut Febriana (2011) Pada model pembelajaran kooperatif tipe Make A Match terlebih dahulu diadakan latihan kerjasama kelompok. Hal ini 
bertujuan untuk mengenal dan memahami karakteristik masing-masing individu dan kelompok. Berdasarkan uraian diatas, dapat dipahami bahwa; (1) model pembelajaran kooperatif tipe Make A Match bertujuan untuk menumbuhkan sikap saling menghormati, menumbuhkan sikap tanggung jawab, meningkatkan percaya diri dalam menyelesaikan suatu masalah, (2) merupakan model pembelajaran yang menuntut anak didik aktif dalam pembelajaran, keterampilan- (3) lingkungan dalam pembelajaran Make A Match diusahakan demokratis, anak didik diberi kebebasan untuk mengutarakan pendapat. Model pembelajaran Make A Match memadukan prinsip demokratis dimana siswa terlibat secara aktif dalam kegiatan pembelajaran, baik dari awal sampai akhir pembelajaran termasuk didalamnya siswa mempunyai kebebasan untuk memilih materi yang akan dipelajari sesuai dengan topik yang sedang dibahas (Shoimin,2014).

Motivasi merupakan dorongan dalam diri siswa yang membuat siswa dapat menciptakann suatu pola interaksi dengan lingkungan. Motivasi siswa dalam pembelajaran dipengaruhi oleh rangsangan, sehingga mampu membangkitkan dorongan atau keinginan dan membuat siswa ingin melakukan sesuatu. Oleh karena itu, seorang guru harus dapat memberikan dorongan kepada siswa. Hal ini bertujuan agar siswa tumbuh motivasi yang mampu membangkitkan semangat dan kegiatan siswa untuk belajar. Hasil belajar merupakan perubahan tingkah laku yang di peroleh seseorang akibat belajar.

Menurut (Sudjana N. , 2014), hasil belajar mencakup tiga ranah yaitu : (1) ranah kognitif berkaitan dengan pengetahuan; (2) ranah afektif berkaitan dengan sikap; dan (3) ranah psikomotor berkaitan dengan keterampilan. Perubahan tingkah laku dari kegiatan belajar mengakibatkan siswa memiliki penguasaan dan pemahaman terhadap materi pengajaran yang sebelumnya telah ditetapkan tujuannya.

\section{Metode}

Metode yang digunakan dalam penelitian ini adalah kuantitatif. Didalam penelitian kuantitatif terdapat penelitian eksperimen. Berdasarkan (Sugiyono, 2016) mengemukakan bahwa dalam penelitian eksperimen ada perlakuan atau (treatment). Oleh karena itu, metode eksperimen dapat diartikan sebagai metode penelitian yang digunakan untuk mencari pengaruh perlakuan tertentu terhadap yang lain dalam kondisi yang terkendalikan. Metode kuantitatif dalam penelitian ini memiliki desain penelitian yaitu Quaisi Experimenta Design. Desain ini mempunyai kelompok kontrol, tetapi tidak dapat berfungsi sepenuhnya untuk mengontrol variabel-variabel luar yang mempengaruhi pelaksanaan eksperimen (Sugiyono, 2014). Bentuk desain yang digunakan dalam penelitian ini adalah Nonequivalent Control Group Design. Desain ini hampir sama dengan pretest-posttest control group design, hanya pada desain ini kelompok eksperimen maupun kelompok kontrol tidak dipilih secara random.

\section{Hasil dan Pembahasan}

Berdasarkan hasil penelitian, peneliti dapat memperoleh data penelitian dan pembahasan tentang pengaruh model pembelajaran kooperatif tipe make a match terhadap motivasi dan hasil belajar matematika siswa kelas V SD Negeri Balun Banjarnegara . Pada model pembelajaran kooperatif tipe make a match dilakukan di dua kelas yaitu kelas VA sebagai kelas eksperimen dan kelas VB sebagai kelas kontrol. Kondisi awal siswa sebelum pelaksanaan penelitian yaitu sebagian besar nilai siswa berada di bawah Kriteria Ketuntasan Minimal (KKM), hal ini karena cara belajar siswa di sekolah kurang aktif dan efektif di kelas. Banyak siswa yang gaduh dengan teman sebangkunya saat pelajaran, sehingga membuat siswa kurang fokus dengan materi yang disampaikan guru. Oleh karena itu, peneliti mengadakan penelitian dengan judul pengaruh model pembelajaran kooperatif tipe make a match terhadap motivasi dan hasil belajar matematika siswa ke las V SD Negeri 1 Balun Banjarnegara.

Data tes yang digunakan adalah dalam bentuk pre-test dan post-test. Perbedaan nilai rata-rata motivasi dan hasil belajar pre-test dan post-test menunjukan perbandingan rata-rata motivasi dan hasil belajar yang besar, baik motivasi dan hasil belajar pada kelas eksperimen maupun kelas kontrol. Hasil kedua sampel menunjukan bahwa rata-rata motivasi nilai pre-test kelas eksperimen adalah 57,73 dan rata-rata pre-test kelas kontrol adalah 57,38 sedangkan rata-rata hasil belajar nilai pre-test kelas eksperimen 44,32 dan rata-rata hasil belajar nilai pre-test kontrol adalah 46,19. Hal ini menunjukan kedua sampel berawal pada kondisi sama yang ma sih rendah. Pada post-test, hasil kedua sampel menunjukan bahwa rata-rata motivasi belajar nilai post-test kelas eksperimen adalah 62,73 , dan rata-rata nilai posttest kelas kontrol 57,86 sedangkan rata-rata hasil belajar nilai post-test kelas eksperimen adalah 65,91 dan rata-rata post-test kelas kontrol adalah 49,05.Motivasi dan hasil belajar post-test pada kelas eksperimen lebih besar dibandingkan kelas kontrol. Hal ini menunjukan adanya perlakuan yang berbeda pada kelas eksperimen dan kelas kontrol. Pada kelas eksperimen siswa diberikan model pembelajaran make a match sehingga motivasi dan hasil belajar yang diperoleh lebih tinggi dan berpengaruh terhadap 
motivasi dan hasil belajar siswa. Sedangkan kelas kontrol memiliki motivasi dan hasil belajar yang lebih rendah dan sedikit berpengaruh terhadap motivasi dan hasil belajar siswa, hal ini karena pada kelas kontrol hanya diberikan metode konvensional tanpa menggunakan model pembelajaran.

Penelitian yang sudah dilakukan di SD Negeri 1 Balun Banjarnegara yaitu dengan adanya model pembelajaran kooperatif tipe make a match maka siswa mengalami perubahan tingkah laku diantaranya siswa menjadi lebih aktif ketika siswa belajar serta siswa mampu bekerja sama dengan baik, sesuai pendapat (Slameto, 2010) yang menyatakan bahwa belajar adalah proses usaha untuk memperoleh perubahan tingkah laku sebagai hasil pengalaman dalam interaksi dengan lingkungan. Dengan adanya perubahan tingkah laku tersebut, maka siswa menjadi terbiasa untuk aktif dalam kegiatan, mampu menyusun konsep dan memberi makna dalam mengikuti pembelajaran. Hal tersebut akan berpengaruh terhadap motivasi dan hasil belajar siswa. Pengaruh motivasi dan hasil belajar ini dikarenakan siswa aktif dalam menganalisa dan mendapat tantangan untuk dipecahkan dan bekerja sama dengan menggunakan lembar kerja siswa pada model pembelajaran kooperatif tipe make a match. siswa akan lebih paham dengan konsep pada materi yang dipelajari. Dengan melakukan suatu kegiatan, maka pembelajaran akan lebih bermakna, sesuai dengan teori belajar menurut pandangan kontruktivistik dalam (Siregar, 2014), belajar merupakan suatu proses pembentukan pengetahuan. Pengetahuan yang didapatkan siswa dari proses pembelajaran yaitu siswa menjadi lebih tau, sehingga nilai siswa menjadi lebih baik.

Motivasi dan hasil belajar diperoleh akibat dilakukannya suatu kegiatan pembelajaran yang mengakibatkan perubahan dalam diri seseorang salah satunya yaitu kegiatan pembelajaran dengan menggunakan model pembelajaran kooperatif tipe make a match pada saat pembelajaran. Terbukti dengan penelitian yang dilakukan pada kelas eksperimen dengan menggunakan model pembelajaran kooperatif tipe make a match, siswa lebih aktif dan senang mengikuti pembelajaran di kelas serta hasil belajar yang memiliki peningkatan.

Pada model pembelajaran kooperatif tipe make a match, siwa dijadikan pusat pembelajaran. Guru tidak mendominasi kegiatan pembelajaran, namu memberikan kesempatan pada siswa untuk mencari dan membangun sendiri pengetahuaanya dala, mata pelajaran Matematika. Model pembelajaran kooperatif tipe make a match merupakan model pembelajaran yang dapat digunakan oleh para guru Matematika dalam mengembangkan kemampuan siswa dalam berfikir, memecahkan masalah, bernalar, dan berkomunikasi. Model pembelajaran make a match merupakan salah satu tipe pembelajaran kooperatif yang disajikan dalam bentuk kartu, mengajak siswa mencari jawaban terhadap suatu pernyataan atau pasangan dari suatu konsep secara kreatif, dengan cara mencari pasangan dari masingmasing konsep yang terdapat pada kartu yang didapatkanya.

Model pembelajaran make a match memberikan peluang kepada siswa untuk aktif mengkontruksikan pengetahuan Matematika mereka dengan pemberian konsep-konsep materi yang dapat diingatkan dan dipahami dengan menyenangkan dalam kelompok belajar yang menuntut kerja sama, kekompakan dan efisien waktu untuk menyelesaikannya sehingga siswa mempunyai motivasi untuk belajar serta hasil belajar yang baik. Dalam penerapan model pembelajaran make a match untuk mempermudah siswa dalam memahami materi pelajaran Matematika. Dengan demikian, penerapan model pembelajaran make a match dapat memberikan suasana menyenangkan.

Berdasarkan hasil analisis akhir yang telah dilakukan dengan uji normalitas dan uji homogenitas menunjukan bahwa kedua sampel berasal dari populasi yang berdistribusi normal dan homogen, sehingga dilakukan uji t. Dalam perhitungan uji $t$ untuk motivasi belajar diperoleh harga $t_{\text {hitung }}=2,995$ sedangkan harga $t_{\text {tabel }}=2,021$, karena $t_{\text {hitung }}>t_{\text {tabel }}$, maka hipotesis nol ditolak dan hipotesis alternatif diterima.

\section{Simpulan dan Saran}

Berdasarkan penelitian yang dilakukan di SD Negeri 1 Balun Banjarnegara maka dapat disimpulkan bahwa penerapan model pembelajaran kooperatif tipe make a match pada materi bangun datar kelas $\mathrm{v}$ memiliki pengaruh terhadap motivasi dan hasil belajar siswa antara lain: (1) Pengaruh model pembelajaran kooperative tipe make a match berpengaruh terhadap motivasi belajar siswa mata pelajaran matematika kelas V SD Negeri 1 Balun Banjarnegara dengan di buktikan melalui uji t. Perhitungan uji t diperoleh nilai $t_{\text {hitung }}$ pada kelas eksperimen dan kelas kontrol adalah 2,995 dan nilai $t_{\text {tabel }}$ 2,021 Karena $t_{\text {hitung }}>t_{\text {tabel }}$ yaitu 2,995 $>2,021$, maka hipotesis yang berbunyi " model pembelajaran kooperatif tipe make a match berpengaruh terhadap motivasi belajar siswa mata pelajaran Matematika kelas V SD Negeri 1 Balun Banjarnegara “. (2) Penggunaan model pembelajaran kooperatif tipe make a match berpengaruh terhadap hasil belajar siswa mata pelajaran Matematika kelas V SD Negeri 1 Balun Banjarnegara dengan di buktikan melalui uji t. Perhitungan uji t diperoleh nilai thitung pada kelas eksperimen dan kelas kontrol adalah 6,502 dan $t_{\text {tabel }} 2,021$. Karena $t_{\text {hitung }}>t_{\text {tabel }}$ yaitu 6,502 $>2,021$, maka 
hipotesis yang berbunyi " model pembelajaran kooperatif tipe make a match berpengaruh terhadap hasil belajar siswa mata pelajaran Matematika kelas V SD Negeri 1 Balun Banjarnegara “.

Setelah melakukan penelitian tentang pengaruh model pembelajaran kooperatif tipe make a match terhadap motivasi dan hasil belajar matematika siswa kelas V SD Negeri Balun Banjarnegara, penulis memberikan saran yang dapat dijadikan rekomendasi untuk berbagai pihak diantaranya untuk guru dan untuk orang tua. Beberapa saran yang ingin penulis sampaikan diantaranya: 1) Bagi Guru, Untuk menciptakan suasana pembelajaran yang menarik, guru dapat mencoba menggunakan model pembelajaran kooperatif tipe make a match untuk di terapkan pada saat pembelajaran. salah satunya adalah mata pelajaran matematika. Tujuannya adalah untuk meningkatkan semangat belajar agar dapat meningkatkan motivasi dan hasil belajar siswa. 2) Bagi Sekolah, Untuk menunjang kegiatan pembelajaran yang baik, hendaknya sekolah memberikan dukungan penuh terhadap pelaksanaan kegiatan belajar mengajar dengan menyediakan fasilitas yang memadai untuk membantu kesulitan yang dialami guru dalam mengelola kelas. Hal ini bertujuan supaya tercapai tujuan pembelajaran dengan baik di dalam maupun di luar kelas. 3) Bagi Peneliti, Dalam penerapan model pembelajaran kooperatif tipe make a match harus mampu menguasai kelas dan mampu menginovasi model ini dengan penambahan permainan yang menarik, agar siswa lebih semangat dalam mengikuti pelaksanaan pembelajaran, peneliti harus bisa mengoptimalkan waktu yang telah di tentukan.

\section{Daftar Rujukan}

Aisyah, Nur Lindah, Luthfiyah Nurlaela. (2015). Penerapan Model Pembelajaran Kooperatif Tipe Make A Match untuk Meningkatkan Hasil Belajar Siswa Kelas X Jasa Boga pada Kompetensi Dasar Potongan Bahan Makanan di SMK Negeri 1 Cerme, Gresik. e-journal Boga, Vol. 4 No. 1 Hal. 143-152. Tersedia Pada : https://jurnalmahasiswa.unesa.ac.id/index.php/jurnal-tata-boga/article/view/10349.

Aliputri, Dhestha Hazilla. (2018). Penerapan Model Pembelajaran Kooperatif Tipe Make A Match Berbantuan Kartu Bergambar untuk Meningkatkan Hasil Belajar Siswa. Jurnal Bidang Pendidikan Dasar (JBPD), Vol.2 No. 1A Hal. 70-77. Tersedia Pada : http: ejournal.unikama.ac.id/index.php/JBPD.

Anggarawati, G. A. (2014). Pengaruh Make A Match Berbantu Media Kartu Gambar Terhadap Hasil Belajar Matematika SD. Jurnal Mimbar PGSD , Vol. 2 No1.

Arikunto, S. (2010). Prosedur Penelitian Suatu Pendekatan Praktik. Jakarta: Rineka cipta.

Astika, N. \& Nyoman, N. A. (2011). Efektivitas model pembelajaran kooperatif tipe make a match terhadap hasil belajar. Jurnal Pendidikan Program Studi Pendidikan Fisika IKIP PGRI Semarang, Vol. 28 No. 110 Hal. 110-117. Tersedia Pada http://jurnal.untad.ac.id/jurnal/index.php/JAK/article/view/10386.

Aunurahman. (2014). Belajar dan Pembelajaran. Bandung: Alfabeta.

Deschuri, Cani, Dadang Kurnia, Diah Gusrayani. (2016). Penerapan Model Kooperatif Teknik Make A Match dengan Media Kartu Klop untuk Meningkatkan Hasil Belajar Siswa Pada Materi Kenampakan Alam dan Buatan. Jurnal Pena Ilmiah: Vol. 1, No. 1 Hal. 361-370. Tersedia Pada : http://ejournal.upi.edu/index.php/penailmiah/article/view/3042.

Dimyati, \& Mudjiono. (2009). Belajar dan Pembelajaran. jakarta: PT Rineka Cipta.

Durukun, E. (2011). Effect of cooperative integrated reading an composition (CIRC) technique on readingwriting skills educational research and reviews. Academic Journals, Vol. 6 No. 1 Hal. 102-109. Tersedia Pada : https://eric.ed.gov/?id=EJ923632.

Ernawati. (2016). Model Koperatif Make A Match untuk Meningkatkan Hasil Belajar dan Aktivitas Belajar IPS Siswa Kelas IV. J.Edu Vol. 2 No. 1 Hal. 80-85. Tersedia Pada : http://jurnal.iicet.org/.

Fadilah, Vivit Nurul, Imam Muchtar, Chumi Zahroul Fitriyah. (2014). Penerapan Model Pembelajaran Kooperatif Tipe Make a Match untuk Meningkatkan Aktivitas dan Hasil Belajar Siswa Kelas III Mata 
Pelajaran Pkn Tema Harga Diri di SDN Ampel 04 Wuluhan Jember. ARTIKEL ILMIAH MAHASISWA, 2014, I (1) Hal. 1-5. Tersedia Pada : http://repository.unej.ac.id/handle/123456789/64171.

Febriana, Ayu. (2011). Penerapan Model Pembelajaran Kooperatif Tipe Make A Match untuk Meningkatkan Kualitas Pembelajaran IPS Siswa Kelas V SDN Kalibanteng Kidul 01 Kota Semarang. Jurnal Kependidikan Dasar Volume 1, Nomor 2, Hal. 151-161. Tersedia Pada : https://journal.unnes.ac.id/nju/index.php/kreatif/article/view/1678.

Hamdani. (2011). Strategi Belajar Mengajar. Bandung: Pustaka Setia.

Hanifah, \& Suhana. (2012). Konsep Strategi Pembelajaran. Bandung: PT Refika Aditama.

Huda, M. (2014). Model-model Pengajaran dan Pembelajaran. Yogyakarta: Pustaka Pelajar.

Ibrahim, S. (2012). Pembelajaran Matematika Teori dan Aplikasinya. Yogyakarta: SUKA-PRESS.

Juhji. (2017). Model Pembelajaran Kooperatif Tipe Make A Match dalam Pembelajaran IPA. PRIMARY Vol. 0901 No. 010 Hal. $9-16 . \quad$ Tersedia http://jurnal.uinbanten.ac.id/index.php/primary/article/view/313/312.

MKPBM, T. (2001). STRATEGI PEMBELAJARAN MATEMATIKA KONTEMPORER. Bandung: JICAUniversitas Pendidikan Indonesia (UPI).

Ngatmini, I. d. (2012). Perencanaan Pembelajaran Bahasa Indonesia. Semarang: IKIP Pres.

Purwanto. (2009). Evaluasi Hasil Belajar. Yogyakarta: Pustaka Pelajar.

Purwoko, \& Fendi. (2007). Fisika SMA/MA Kelas X. Yudhistira.

Rusman. (2017). Belajar dan Pembelajaran berorientasi Standar Proses Pendidikan. Jakarta: Kencana.

Saefuddin, A. (2015). Pembelajaran Efektif. Bandung: PT Remaja Rosdakarya.

Saparwadi, L. (2015). Pengaruh Cooperative Learning Tipe Make A Match Terhadap Motivasi dan Hasil Belajar Matematika Siswa. Pendidikan, Vol.8 No.1.

Sardiman. (2014). Interaksi dan Motivasi Belajar Mengajar. Jakarta: PT Raja Grafindo Persada.

Shoimin, A. (2014). 68 Model Pembelajaran Inovatif Dalam Kurikulum 2013. Yogyakarta: Ar-Ruzz Media.

Siregar, Eveline \& Nara, \& Hartati. (2014). Teori Belajar dan Pembelajaran . Bogor: Galia Pembelajaran.

Slameto. (2010). Belajar dan faktor-Faktor yang Mempengaruhinya . Jakarta : Rineka Cipta.

Sudjana. (2005). Metoda Statistika. Bandung: Tarsito.

Sudjana, N. (2014). Penilaian Hasil Proses Belajar Mengajar.Bandung: PT Remaja Rosdakarya.

Sugiono. (2018). Metode Penelitian Kuantitatif . Bandung: ALFABETA.

Suprijono, A. (2011). Cooperative Learning Teori \& Aplikasi PAIKEM. Yogyakarta: Pustaka Pelajar.

Susanto, \& Ahmad. (2013). Teori Belajar dan Pembelajaran di Sekolah Dasar. Jakarta: Prenadamedia Group.

Tiballa, Meida Dwi Sana, Dewa Nyoman Sudana, I Ketut Gading. (2017). Pengaruh Model Pembelajaran Kooperatif Tipe Make A Match Berbantuan Peta Pikiran terhadap Hasil Belajar IPA Siswa Kelas V Sekolah Dasar. e-Journal PGSD Universitas Pendidikan Ganesha Mimbar PGSD Vol. 5 No. 2 Hal. 1- 
10. Tersedia

Pada

https://ejournal.undiksha.ac.id/index.php/JJPGSD/article/viewFile/10718/6821.

Uno, B. H. (2016). Teori Motivasi dan Pengukuran : Analisis di Bidang Pendidikan. Jakarta: PT Bumi Aksara.

Wicaksono, D. S., \& Hakim, F. N. (2011). Media Pembelajaran Fisika nteraktiv Bahasan alor Berbasis Flash dan Xmi. Journal Speed (Sentra Penelitian Engineering dan Edukasi). 